TITLE:

\title{
Involvement of autophagy in the pharmacological effects of the mTOR inhibitor everolimus in acute kidney injury.
}

AUTHOR(S):

Nakagawa, Shunsaku; Nishihara, Kumiko; Inui, Ken-Ichi; Masuda, Satohiro

\section{CITATION:}

Nakagawa, Shunsaku ...[et al]. Involvement of autophagy in the pharmacological effects of the mTOR inhibitor everolimus in acute kidney injury.. European journal of pharmacology 2012, 696(1-3): 143-154

ISSUE DATE:

2012-12-05

URL:

http://hdl.handle.net/2433/163079

\section{RIGHT:}

(c) 2012 Elsevier B.V.; この論文は出版社版でありません。引用の際には 出版社版をご確認ご利用ください。; This is not the published version. Please cite only the published version. 


\title{
Involvement of autophagy in the pharmacological effects of the mTOR inhibitor everolimus in acute kidney injury
}

\author{
Shunsaku Nakagawa, Kumiko Nishihara, Ken-ichi Inui, Satohiro Masuda* \\ Department of Pharmacy, Kyoto University Hospital, Sakyo-ku, Kyoto 606-8507, Japan
}

\section{A R T I C L E I N F O}

\section{Article history:}

Received 27 April 2012

Received in revised form

5 September 2012

Accepted 17 September 2012

\section{Keywords:}

Mammalian target of rapamycin

Autophagy

Proximal tubule

Acute kidney injury

Biomarker

***This is an author version

based on a template provided by Elsevier.

\begin{abstract}
A B S T R A C T
Inhibitors of mammalian target of rapamycin (mTOR) have immunosuppressive and anti-cancer effects, but their effects on the progression of kidney disease are not fully understood. Using cells from normal kidney epithelial cell lines, we found that the antiproliferative effects of mTOR inhibitor everolimus accompanied the accumulation of a marker for cellular autophagic activity, the phosphatidylethanolamine-conjugated form of microtubule-associated protein 1 light chain 3 (LC3-II) in cells. We also showed that the primary autophagy factor UNC-51-like kinase 1 was involved in the antiproliferative effects of everolimus. Levels of LC3-II decreased in the kidneys of rats treated with ischemia-reperfusion or cisplatin; however, renal LC3-II levels increased after administration of everolimus to rats subjected to ischemia-reperfusion or cisplatin treatment. Simultaneously, increased signals for kidney injury molecule-1 and single-stranded DNA and decreased signals for Ki-67 in the proximal tubules were observed after treatment with everolimus, indicating that everolimus diminished renal function after acute tubular injury. We also found leakage of LC3 protein into rat urine after treatment with everolimus, and urinary LC3 protein was successfully measured between 0.1 and $500 \mathrm{ng} / \mathrm{mL}$ by using an enzyme-linked immunosorbent assay. Urinary LC3 levels were increased after administration of everolimus to rats subjected to ischemia-reperfusion or cisplatin treatment, suggesting that renal LC3-II and urinary LC3 protein are new biomarkers for autophagy in acute kidney injury. Taken together, our results demonstrated that the induction of autophagy by everolimus aggravates tubular dysfunction during recovery from kidney injury.
\end{abstract}

(c) 2012 Elsevier B.V. All rights reserved.

\section{Introduction}

Everolimus is as an immunosuppressive macrolide derived from sirolimus (rapamycin) that inhibits the kinase activity of mammalian target of rapamycin (mTOR) (Wullschleger et al., 2006). The renal toxicity of everolimus is thought to be lower than that of other agents, such as calcineurin inhibitors (e.g., cyclosporine or tacrolimus, which are often used as primary immunosuppressants after organ transplantation) (Lehmkuhl et al., 2005; Schweiger et al., 2006). However, de novo use of mTOR inhibitors after renal transplantation has been reported to cause decreased renal graft survival (Ekberg et al., 2007) and delayed wound healing (Kahn et al., 2005).

Previous studies in models of progressive kidney disease have shown that sirolimus and everolimus have preventive effects on renal hypertrophy and fibrosis (Huber et al., 2011). Recently, we demonstrated that the mTOR pathway is activated in the proximal tubular cells of rat kidneys after subtotal nephrectomy (Nakagawa

\footnotetext{
* Correspondence author. Tel.: +8175 751 3586;

fax: +81757514207

E-mail address: masuda@kuhp.kyoto-u.ac.jp (S. Masuda).
}

et al., 2010). We found that treatment with everolimus in rats 8 weeks after subtotal nephrectomy, an animal model of end-stage renal disease, had restorative effects on the tubular reabsorption of albumin and the expression levels of membrane transporters in the proximal tubules. However, mTOR inhibitors also display adverse effects on the kidneys. Treatment with mTOR inhibitors in ischemia-reperfusion injury deteriorates the renal function of rats and mice by preventing recovery (Esposito et al., 2011; Lieberthal et al., 2001). In addition, we found that everolimus treatment in rats 2 weeks after subtotal nephrectomy, an animal model of compensative chronic renal failure, prevented cellular hyperplasia of the proximal tubules, resulting in severe renal damage (Nishihara et al., 2010). These findings suggest that mTOR inhibitors could contribute to renal toxicity by inhibiting the adaptive response of tubular cells during acute kidney injury, and therefore, biomarkers are needed to predict treatment outcomes with mTOR inhibitors during kidney injury.

The mTOR pathway is known to regulate autophagy (Wullschleger et al., 2006). Recent studies have shown that the active mTOR pathway suppresses autophagy by preventing UNC51-like kinase 1 (Ulk1) activity (Chan et al., 2007). Autophagy is an evolutionarily conserved process through which organelles or long-lived proteins are sequestered in a double-membrane vesicle 
A

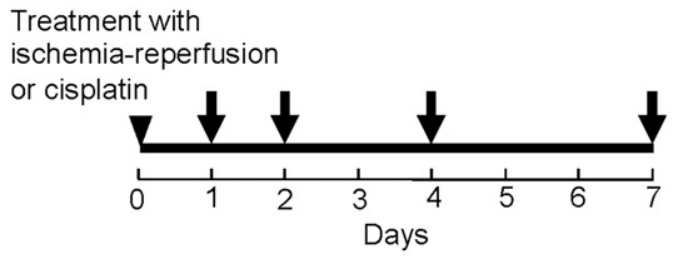

B

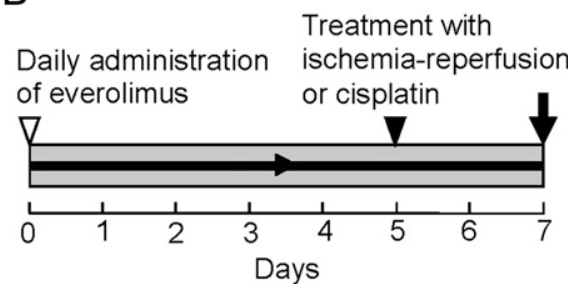

Fig. 1. Experimental designs. (A) Kidneys were collected 1, 2, 4, and 7 days after treatment to examine the effects of ischemia-reperfusion or cisplatin alone. (B) Rats were administered everolimus ( $2 \mathrm{mg} / \mathrm{kg}$ body weight per day) or vehicle subcutaneously for 7 days to examine effects of everolimus. On the fifth day, the rats were subjected to ischemia-reperfusion or treated with cisplatin. Black arrowheads, treatment with ischemia-reperfusion or cisplatin; white arrowhead, initiation of administration of everolimus; arrows, sample collection; gray bar, administration of everolimus. "autophagosome" and subsequently degraded in lysosomes (Levine and Kroemer, 2008). Because the cytosolic form of microtubule-associated protein 1 light chain 3 (LC3-I) is modified into its phosphatidylethanolamine-conjugated form, LC3-II, which is associated with autophagosomes, LC3-II has been examined as a marker for autophagic activity (Mizushima et al., 2010). Recent studies have focused on the roles of autophagy in kidney disease; however, the influence of mTOR activation on the LC3-II levels in the kidneys remains to be delineated.

Given these findings, we examined the association between the mTOR pathway and autophagy in the kidney. Our results demonstrated that mTOR inhibition with everolimus induced the renal accumulation of LC3-II in acute kidney injury, preventing tubular cell proliferation after injury. We also identified the presence of LC3 protein in rat urine and found that the quantification of urinary LC3 was beneficial in the evaluation of the pharmacological activity of mTOR inhibitors in the kidney.

\section{Materials and methods}

\subsection{Animals}

Wistar/ST rats were purchased from SLC Animal Research Laboratories (Shizuoka, Japan) and cared for in accordance with
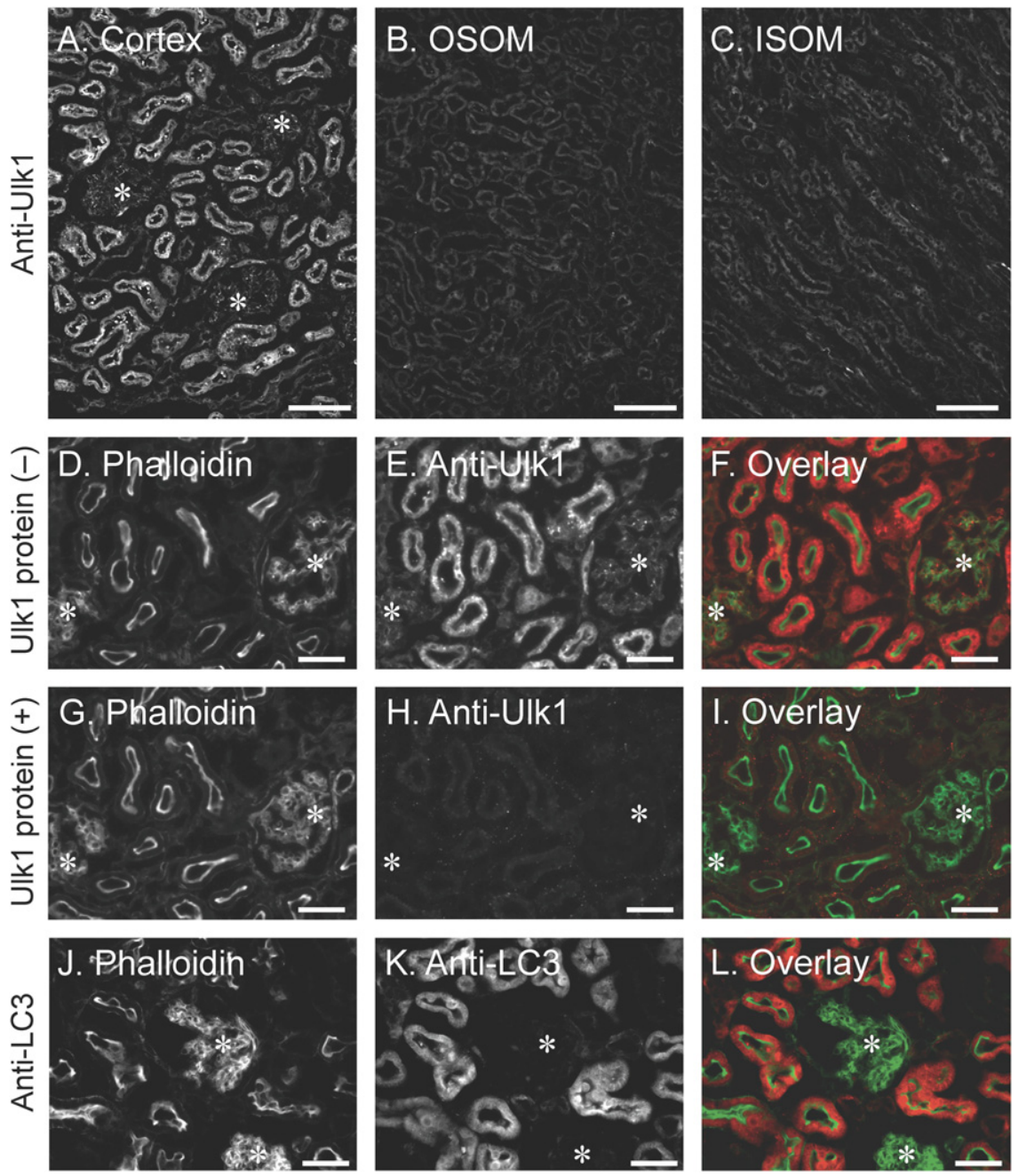

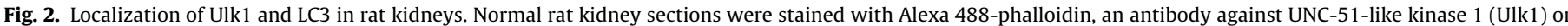

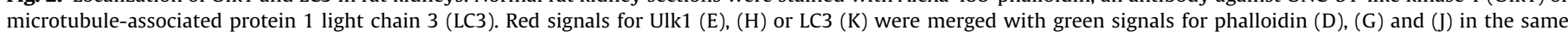

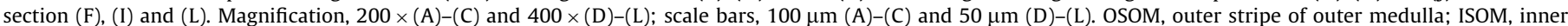
stripe of outer medulla. $\left({ }^{*}\right)$, glomeruli. 
the Guidelines for Animal Experiments of Kyoto University. All protocols were approved by the Animal Research Committee, Graduate School of Medicine, Kyoto University. For studies on the effects of starvation, 8-week-old rats were deprived of food for 0 or $48 \mathrm{~h}$. These rats had free access to drinking water. To investigate the effects of ischemia-reperfusion, we subjected 8 -weeks-old rats to ischemia-reperfusion following a protocol published elsewhere (Gonçalves et al., 2006). In brief, both renal pedicles were cross-clamped for $40 \mathrm{~min}$. During the procedure, animals were well hydrated with saline and maintained at a constant temperature $\left(37^{\circ} \mathrm{C}\right)$ using a heating pad. Sham-operated rats at 2 days after surgery were used as controls. To induce nephrotoxicity with cisplatin, we intraperitoneally administered cisplatin $(5 \mathrm{mg} / \mathrm{kg}$; Randa $\mathbb{R}$; Nippon Kayaku Co., Ltd., Tokyo, Japan) to 8-week-old rats. Control rats were administered the same volume of saline. Kidneys were collected 1, 2, 4, and 7 days after ischemia-reperfusion or cisplatin treatment (Fig. 1A). The levels of blood urea nitrogen and plasma creatinine ( $\mathrm{PCr}$ ) were measured to examine renal function by using assay kits from
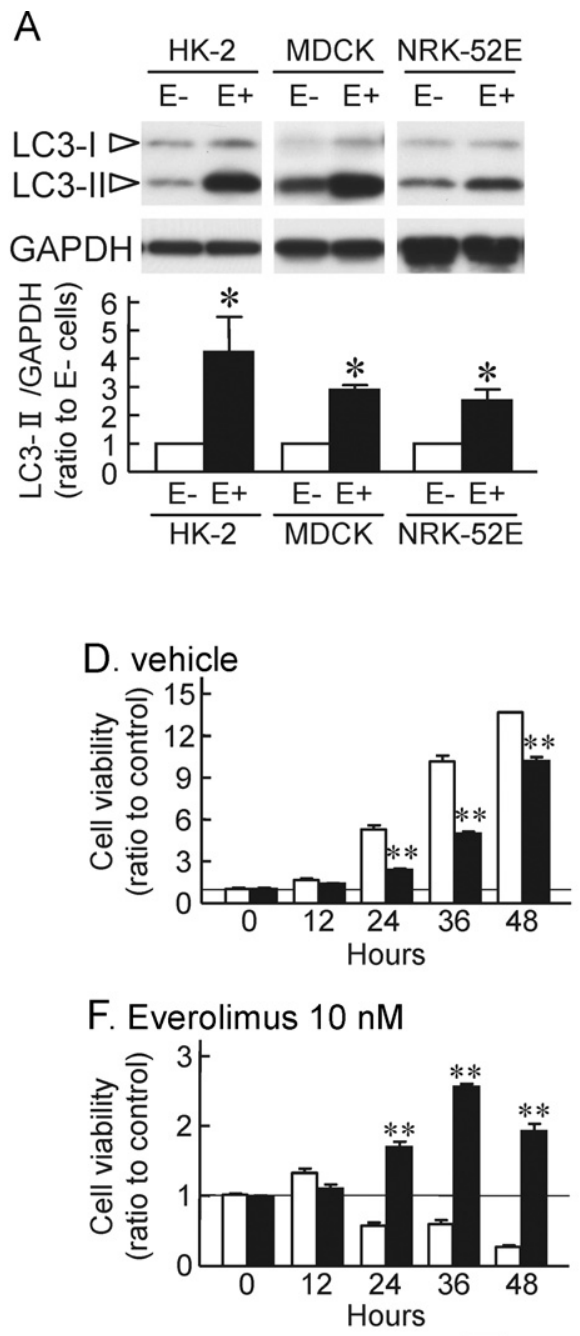

siControl
Skeletal muscle

B
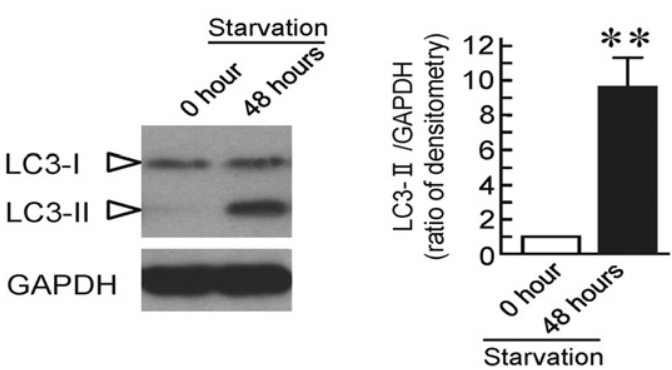

Fig. 4. Examination of LC3-II levels in rat skeletal muscles after starvation. (A) Whole-tissue homogenates were prepared from skeletal muscles after a 0 - or 48 -h starvation and subjected to western blotting using antibodies against LC3 and GAPDH. (B) The relative densities of the bands in each lane were determined, and the ratio of the density of the cells of starved rats to that of the cells of control rats was calculated. GAPDH was used as an internal standard. ${ }^{* *} P<0.01$, significantly different from control rats.

B
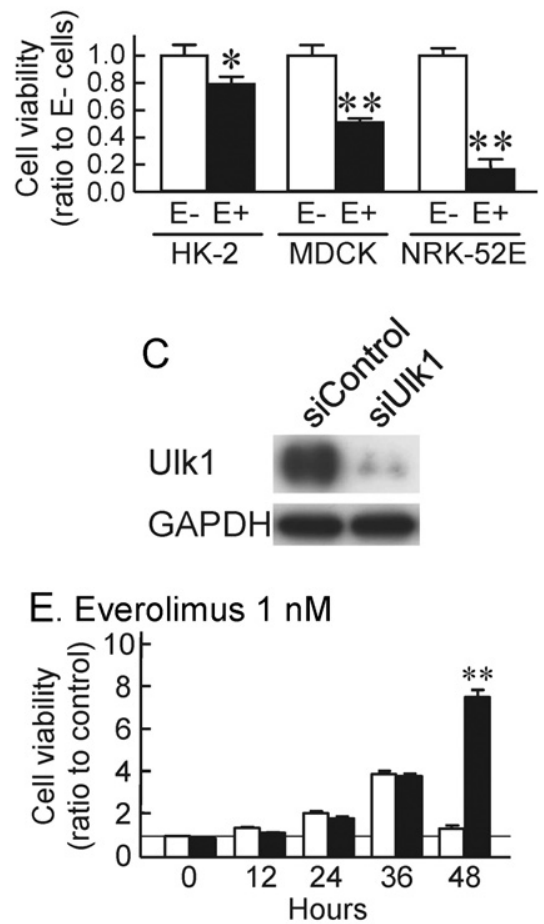

G. Everolimus $100 \mathrm{nM}$

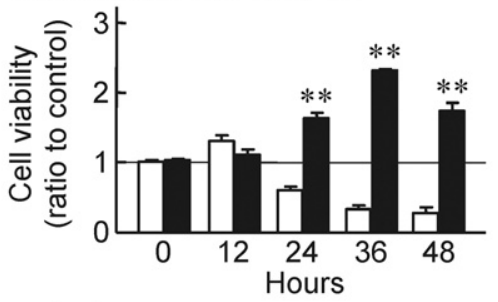

siUlk1

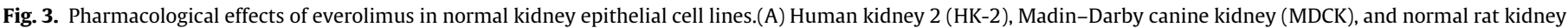

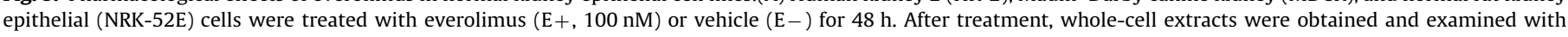

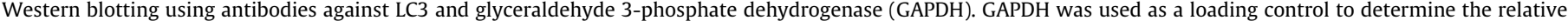

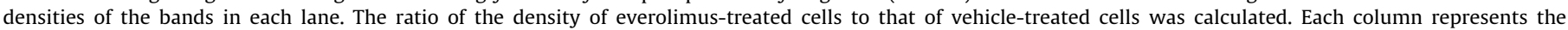

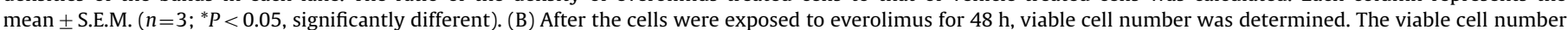

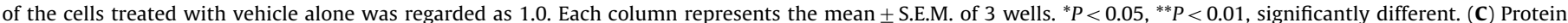

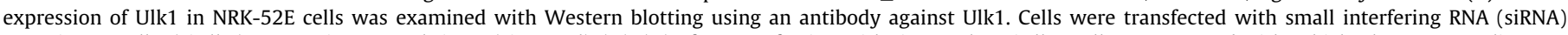

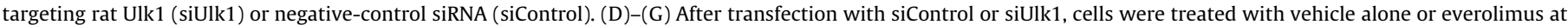
various concentrations. The viability of the control cells at $0 \mathrm{~h}$ was regarded as 1.0. Each point represents the mean \pm S.E.M. $(n=3)$. 
Wako Pure Chemical Industries (Osaka, Japan). The urinary protein concentration was determined using a Bradford protein assay (Bio-Rad Laboratories, Hercules, CA).

Rats were subcutaneously administered everolimus $(2 \mathrm{mg} / \mathrm{kg}$ body weight per day; LC Laboratories, Woburn, MA) or vehicle (90\% saline, 5\% ethanol, 5\% Cremophor $®$ EL [Nacalai Tesque, Kyoto, Japan]). The rats were administered everolimus for 5 days to obtain a stable everolimus blood concentration (Fig. 1B). On the sixth day, the rats were subjected to ischemia-reperfusion or treated with cisplatin.

\subsection{Cell culture}

Cells from kidney epithelial cell lines (human kidney 2 [HK-2], ATCC CRL-2190; Madin-Darby canine kidney [MDCK], ATCC CCL34; normal rat kidney epithelial [NRK-52E], ATCC CRL-1571; American Type Culture Collection, Manassas, VA) were cultured in complete medium consisting of Dulbecco's modified Eagle's medium (Wako) with $10 \%$ fetal bovine serum (Whittaker Bioproducts Inc., St. Louis, $\mathrm{MO}$ ) in an atmosphere of $5 \% \mathrm{CO}_{2}-95 \%$ air at $37{ }^{\circ} \mathrm{C}$. The effects of everolimus on viable cell number and LC3-II were measured after exposure to everolimus for $48 \mathrm{~h}$.

The effect of everolimus on cell proliferation was determined by adapting a published previously protocol (Iwamaru et al., 2007). Cell viability was determined using a WST-8 cell proliferation reagent kit (Nacalai Tesque) according to the manufacturer's instructions. The cells were seeded into 24 wells at $2 \times 10^{4}$ cells per well and incubated overnight in an atmosphere of $5 \% \mathrm{CO}_{2}-95 \%$ air at $37{ }^{\circ} \mathrm{C}$. After exposure to everolimus $(100 \mathrm{nM})$ for $48 \mathrm{~h}$, the cells were incubated with cell culture medium containing $10 \%$ WST- 8 for $1 \mathrm{~h}$, and the absorbance of the samples against a background control was measured. The viability of the cells treated with vehicle alone was set as 1.0. For the RNA interference system, the sequence of small interfering RNA (siRNA) targeting rat Ulk1 was as follows: $5^{\prime}$-GCUCUCAGAGUUUGCUGACCCUGUU3'. The siRNA was synthesized by Invitrogen Life Technologies (Carlsbad, CA). We used Stealth $₫$ RNAi Negative Control Duplexes (Invitrogen) as the negative control. On the day before transfection, the cells were seeded into 48 -well plates at a density of $7.5 \times 10^{3}$ cells per well. The cells were transfected with 8 pmol per well siRNA by using $0.4 \mu$ L Lipofectamine RNAi MAX $^{\circledR}$ (Invitrogen) according to the manufacturer's instructions. Twenty-four hours after transfection, the cells were treated with vehicle alone or everolimus (1-100 $\mathrm{nM}$ ) for $48 \mathrm{~h}$.

\subsection{Western blotting}

Cells, rat skeletal muscles and rat whole kidneys were homogenized in lysis buffer ( $50 \mathrm{mM}$ Tris- $\mathrm{HCl}(\mathrm{pH} 7.5), 150 \mathrm{mM} \cdot \mathrm{NaCl}$, $10 \mathrm{mM} \cdot \mathrm{NaF}, 1 \mathrm{mM} \cdot \mathrm{Na}_{4} \mathrm{P}_{2} \mathrm{O}_{7}, 1 \mathrm{mM} \cdot \mathrm{Na}_{3} \mathrm{VO}_{4}, 1 \% \mathrm{NP}-40$, and $1 \%$ protease inhibitor cocktail). To solubilize LC3-II completely, we boiled and subsequently separated fresh samples using sodium dodecyl sulfate polyacrylamide gel electrophoresis and transferred them to polyvinylidene difluoride membranes (Merck Millipore, Darmstadt, Germany). Membranes were blocked, washed, and incubated overnight at $4{ }^{\circ} \mathrm{C}$ with primary antibodies to total S6 (Cell Signaling Technology \#2317, Tokyo, Japan), phosphorylated ribosomal protein S6 (p-S6; Cell Signaling Technology \#2211), LC3 (Novus Biologicals NB100-2331, Littleton, CO), glyceraldehyde 3-phosphate dehydrogenase (GAPDH; Santa Cruz Biotechnology sc-59540, Avenue, CA), Ulk1 (Santa Cruz Biotechnology sc-33182), and phosphorylated Ulk1 (p-Ulk1; Cell Signaling Technology \#6888). The bound antibodies were detected on X-ray film by using enhanced chemiluminescence with horseradish peroxidase (HRP)-conjugated secondary antibodies and cyclic diacylhydrazides (Merck Millipore). The relative densities of the bands in each lane were determined using NIH Image J 1.39 (National Institutes of Health, Bethesda, MD).

For the urine analysis, urine samples collected from the bladders of the rats were concentrated using ultrafiltration membrane units (Amicon Ultra $3 \mathrm{kDa}$, Merck Millipore) and diluted with $20 \mathrm{mM}$ Tris-HCl. Concentrated urine was separated using sodium dodecyl sulfate polyacrylamide gel electrophoresis and blotted onto polyvinylidene difluoride membranes. Two antibodies specific for LC3 (Novus Biologicals NB100-2331B and Cell Signaling Technology \#2775) were used as primary antibodies.

\subsection{Measurement of urinary LC3}

Urine was collected from the bladders of the rats and stored at $-80^{\circ} \mathrm{C}$ until use. Urinary LC3 was measured using a sandwich enzyme-linked immunosorbent assay (ELISA). One antibody specific

A

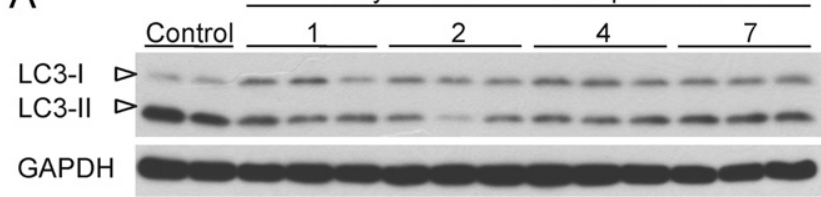

p-Ulk1

total Ulk1 $\rightarrow-\infty-\cdots-\infty-\infty$

p-S6

total S6

B
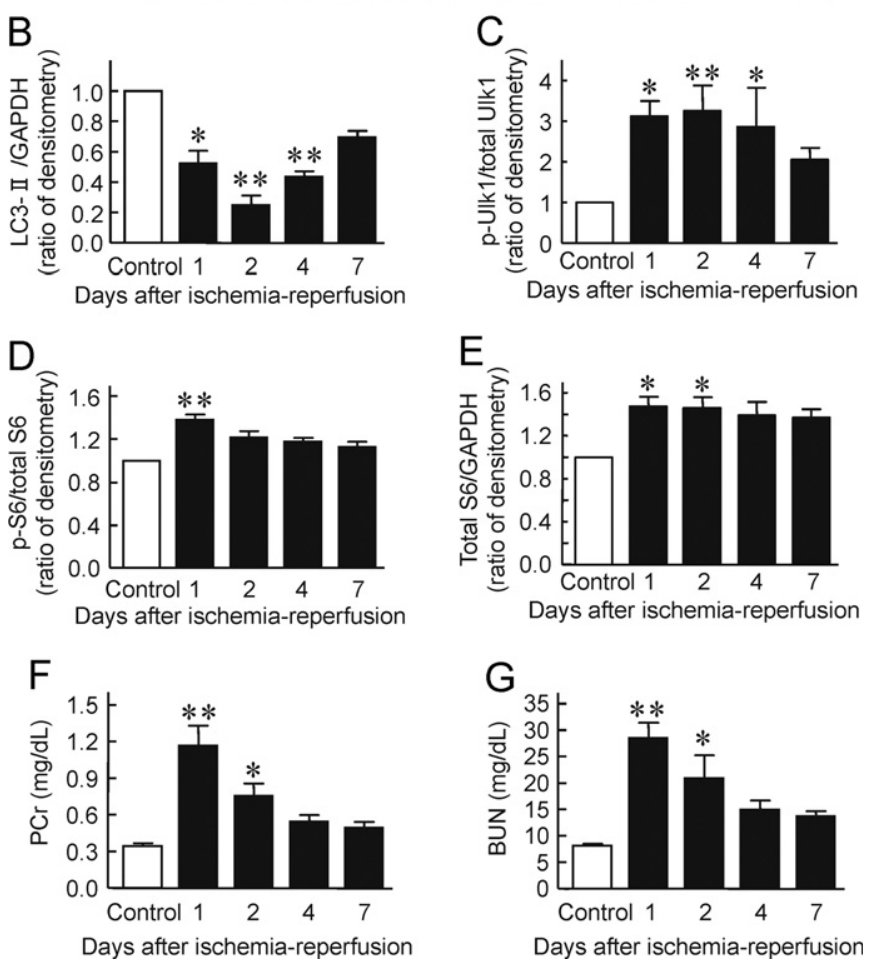

Fig. 5. Effects of ischemia-reperfusion on autophagy in rat kidneys. Rats were subjected to ischemia-reperfusion. Kidneys were collected 1, 2, 4, and 7 days after surgery. Rats in the control group were sham-operated, and kidneys were collected 2 days after surgery. The number of rats in each group was 6 . (A)-(E) Whole-kidney homogenates were subjected to Western blotting. The expression levels of LC3, total Ulk1, phosphorylated Ulk1 (p-Ulk1), total ribosomal protein S6, phosphorylated S6 (p-S6), and GAPDH were examined. (B)-(E) The relative densities of the bands in each lane were determined. (F), (G) Renal function was assessed by measuring plasma creatinine concentration (PCr) and blood urea nitrogen levels. Multiple comparisons were performed using Dunnett's 2-tailed test. ${ }^{*} P<0.05,{ }^{* *} P<0.01$, significantly different from control rat kidneys. 
for LC3 (Cell Signaling Technology \#2775) served as a capture antibody. Another biotinylated LC3 antibody (Novus Biologicals NB100-2331B) was used as a detection antibody. The wells of a 96-well plate (ELISA Starter Accessory Kit, Bethyl Laboratories, Montgomery, TX) were coated with capture antibody (diluted $1: 250$ ) and blocked with $1 \%$ bovine serum albumin in phosphatebuffered saline. Standard LC3 protein (abcam ab87823, Cambridge, UK) in serial dilutions $(0-500 \mathrm{ng} / \mathrm{mL})$ or urine samples were then added to the plate in duplicate. All of the dilutions of LC3 standards, urine samples, antibodies, and HRP-conjugated streptavidin (R\&D Systems, Minneapolis, MN) were performed in the blocking solution. After the washing, detection antibody and then HRP-conjugated streptavidin were added. Color was developed by adding the 3,3,5,5-tetramethylbenzidine substrate (Bethyl Laboratories), and the reaction was stopped by adding $2 \mathrm{~N} \cdot \mathrm{H}_{2} \mathrm{SO}_{4}$. Absorbance was measured at $450 \mathrm{~nm}$ and corrected for plate artifacts at $570 \mathrm{~nm}$. Urinary LC3 concentration was calculated based on the standard curve and expressed in $\mathrm{ng} / \mathrm{mg}$ creatinine.

\subsection{Fluorescence microscopy}

After perfusion with $4 \%$ paraformaldehyde in phosphatebuffered saline, the kidneys were embedded in Tissue-Tek $\mathbb{R}$ O.C.T. compound (Sakura Finetechnical, Tokyo, Japan) and frozen rapidly in liquid nitrogen. To detect Ulk1, LC3, kidney injury molecule-1 (Kim-1), and Ki-67, we cut 5 - $\mu$ m-thick sections of the rat kidney and covered them with $5 \%$ bovine serum albumin containing $0.3 \%$ Triton $\mathrm{X}-100$ at $37{ }^{\circ} \mathrm{C}$ for $60 \mathrm{~min}$. The covered sections were incubated overnight at $4{ }^{\circ} \mathrm{C}$ with primary antibodies specific for Ulk1 (Merck Millipore ST1521), LC3 (Novus Biologicals NB100-2331), Kim-1 (Nakagawa et al., 2010), and Ki67 (abcam ab16667), washed 3 times, and incubated with secondary antibodies (Alexa 546-labeled goat anti-rabbit immunoglobulin G [IgG] or Alexa 546-labeled goat anti-mouse IgG; Life Technologies, Tokyo, Japan), Alexa 488-phalloidin (Life Technologies) and 4',6-diamidino-2-phenylindole (Wako) at $37{ }^{\circ} \mathrm{C}$ for $60 \mathrm{~min}$. As a negative control for Ulk1, primary antibody against Ulk1 was incubated after preabsorption with recombinant fulllength Ulk1 protein (abcam ab95322). To detect single-stranded DNA (ssDNA), we treated 5 - $\mu$ m-thick sections with proteinase $\mathrm{K}$ and heated them in $50 \%$ formamide. The sections were then covered with $3 \%$ non-fat dry milk at $37{ }^{\circ} \mathrm{C}$ for $20 \mathrm{~min}$. The covered sections were incubated for $30 \mathrm{~min}$ at room temperature with a primary antibody specific for ssDNA (Merck Millipore MAB3299), washed 3 times, and incubated with secondary antibodies at room temperature for $30 \mathrm{~min}$. Images for immunofluorescent analysis were captured and examined with a BZ-9000 (Keyence, Osaka, Japan). To evaluate the levels of LC3, Kim-1, Ki-67, and ssDNA, we took 20 independent photographs of the renal cortex (at $1000 \times$ magnification for LC3; at $100 \times$ magnification for Kim1, Ki-67, and ssDNA) and counted the dot structures in the proximal tubules (for LC3), the stained proximal tubules (for Kim-1), or nuclei (for Ki-67 and ssDNA).
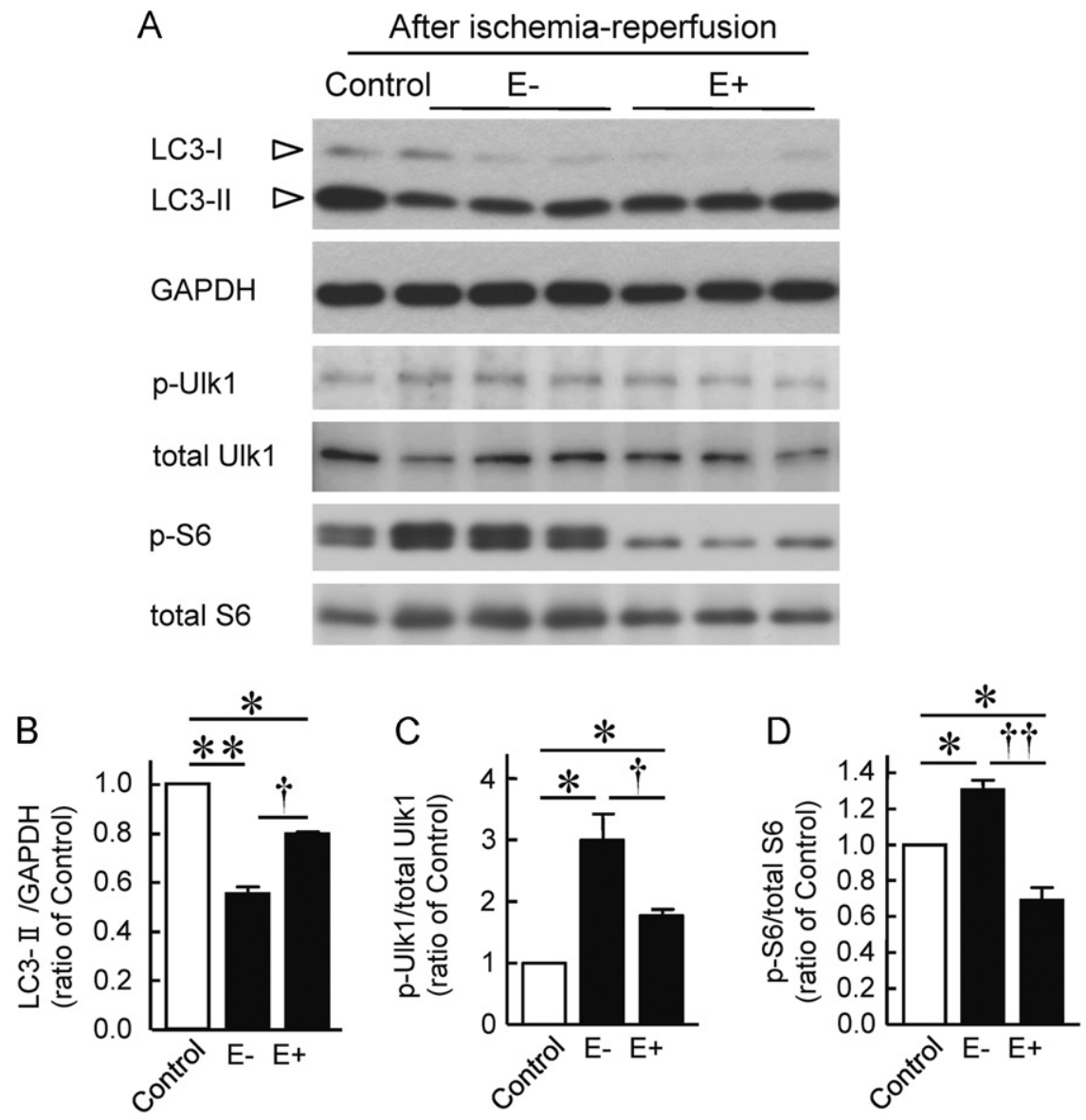

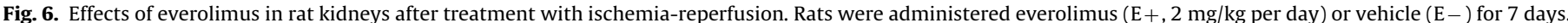

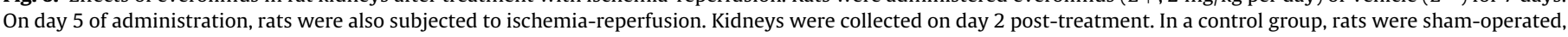

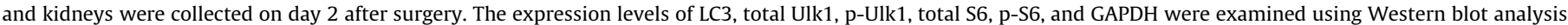
(A). The relative densities of the bands in each lane were determined (B)-(D). ${ }^{*} P<0.05,{ }^{* *} P<0.01,{ }^{\dagger} P<0.05$, ${ }^{\dagger} P<0.01$ show significant difference. 


\subsection{Statistical analysis}

Data are expressed as mean \pm S.E.M. Data were statistically analyzed using the unpaired t test or multiple comparisons after one-way analysis of variance. Probability values of less than 0.05 were considered statistically significant. Statistical analysis was performed using Prism Version 4.0 software (GraphPad, San Diego, CA).

\section{Results}

\subsection{Localization of Ulk1 in rat kidneys}

First, renal localization of Ulk1 was examined using immunofluorescent analysis (Fig. 2). Signals for Ulk1 were predominantly observed in the cortex (Fig. 2A-C). The serial sections were stained with phalloidin and antibodies against Ulk1. Phalloidin conjugated with F-actin, making signals for phalloidin abundant at glomeruli and the luminal side of proximal tubules (Fig. 2D and G). The results showed that the intensities of the signals for Ulk1 were relatively higher in proximal tubular epithelial cells (Fig. 2D-F). The preabsorption of antibody with Ulk1 protein abolished these positive signals (Fig. 2G-I), demonstrating the presence of Ulk1 protein in proximal tubular epithelial cells. Furthermore, the signals for LC3 were observed in the proximal tubular epithelial cells (Fig. 2J-L).

\subsection{Effects of everolimus on renal tubular epithelial cell lines}

To characterize the effects of everolimus on tubular epithelial cells, we carried out in vitro experimentation with the renal tubular epithelial cell lines HK-2, MDCK, and NRK-52E. LC3-II levels in the cells were determined using recommended methods in mammalian autophagy research (Klionsky et al., 2008; Mizushima et al., 2010). In the renal tubular epithelial cell lines, the LC3-II levels were significantly increased in cells exposed to everolimus for $48 \mathrm{~h}$ compared
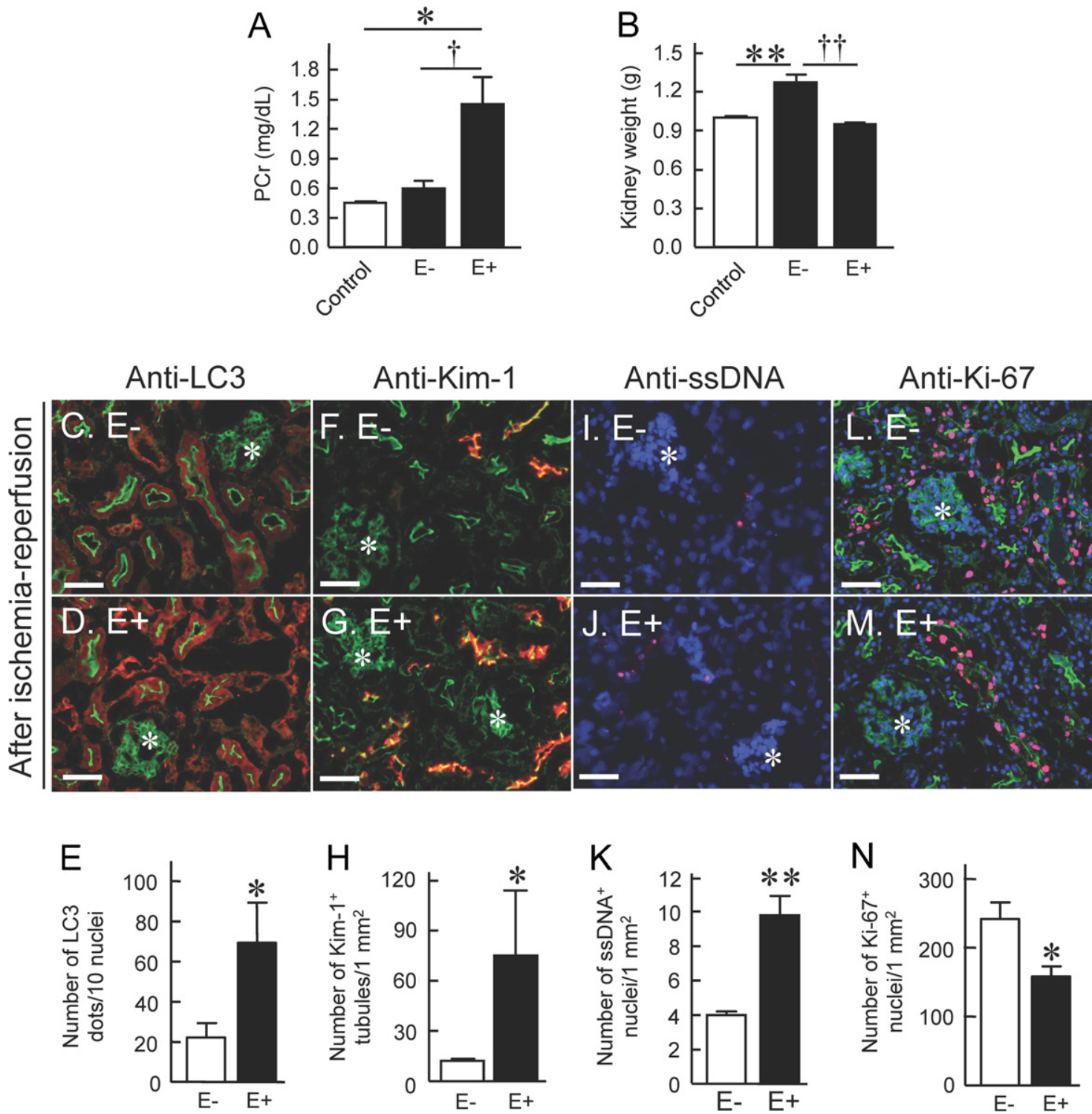

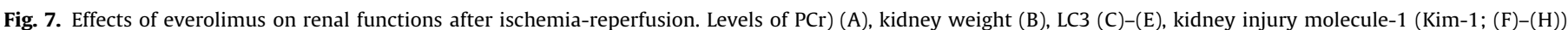

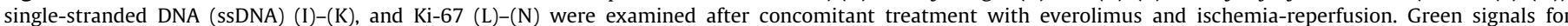

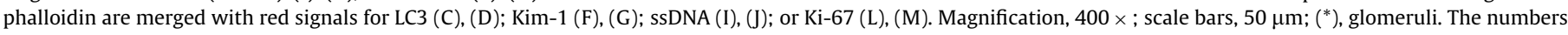

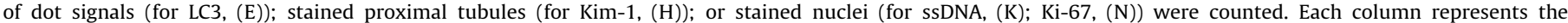
mean \pm S.E.M. $\left({ }^{*} P<0.05,{ }^{* *} P<0.01,{ }^{\dagger} P<0.05\right.$, and ${ }^{\dagger \dagger} P<0.01$ show significant differences $)$. 
with those treated with vehicle (Fig. 3A). Simultaneously, the treatment of everolimus decreased the number of viable cells (Fig. 3B). To determine the involvement of Ulk1 in the effect of everolimus on cell proliferation, we used siRNA-targeting rat Ulk1 (siUlk1). The protein expression levels of Ulk1 in NRK-52E cells were markedly decreased after treatment with siUlk1 (Fig. 3C). Transfection with siUlk1 significantly decreased the cell viability at 24,36 , and $48 \mathrm{~h}$ after treatment with vehicle alone (Fig. 3D). While the treatment with everolimus $(1,10$, and $100 \mathrm{nM})$ markedly inhibited cell proliferation of control cells, transfection with siUlk1 attenuated the antiproliferative effect of everolimus (Fig. 3E-G).

\subsection{Effects of ischemia-reperfusion on the mTOR pathway in the kidney}

Before assessing LC3-II levels in vivo, we validated our methods based on a previous report that the levels of LC3-II in muscle tissue increases after nutrient starvation (Mizushima et al., 2004). The levels of LC3-II in rat skeletal muscles after fasting for 0 or $48 \mathrm{~h}$ was examined. As shown in Fig. 4, fasting for $48 \mathrm{~h}$ significantly increased LC3-II levels in muscles.

Next, we examined the effects of ischemia-reperfusion on the levels of LC3-II, p-Ulk1, and p-S6. ischemia-reperfusion injury was used as a model of acute tubular necrosis. A reduction in renal blood flow during ischemia and subsequent reperfusion caused pronounced tubular necrosis, endothelial injury, and leukocyte activation (Bonventre and Weinberg, 2003). The levels of LC3-II 1, 2 , and 4 days after ischemia-reperfusion were significantly lower than those in normal rat kidneys (Fig. 5A and B). Recent studies showed that mTOR phosphorylates Ulk1 at Ser 757. We found that phosphorylation of Ulk1 in the kidneys increased significantly 1,2 , and 4 days after ischemia-reperfusion (Fig. 5A and C). Levels of p-S6 have been used to distinguish the activation of the mTOR pathway in mice and rat kidneys. Phosphorylated S6 and total S6 levels significantly increased the day after administration (Fig. 5A, D, and E). These results clearly showed that the mTOR pathway was activated after ischemia-reperfusion. In this model, the levels of $\mathrm{PCr}$ and blood urea nitrogen were significantly increased 1 and 2 days after ischemia-reperfusion (Fig. 5F and G).

\subsection{Effects of everolimus in ischemia-reperfusion injury}

We defined the effects of everolimus on the levels of LC3-II, p-Ulk1, and p-S6 in the kidneys after treatment with ischemiareperfusion. Ischemia-reperfusion decreased the levels of LC3-II and, conversely, increased those of p-Ulk1 and p-S6; however, treatment with everolimus restored the levels of LC3-II (Fig. 6A and B and Fig. 7C-E) and decreased the levels of p-Ulk1 and p-S6 (Fig. 6A, C, and D), indicating that the mTOR pathway was activated after ischemia-reperfusion regulated LC3-II levels in the kidney.

We also explored the effects of everolimus on renal function. The $\mathrm{PCr}$ levels after ischemia-reperfusion were markedly increased by pretreatment with everolimus (Fig. 7A). In addition, everolimus pretreatment prevented renal hypertrophy after ischemiareperfusion (Fig. 7B). Kidney sections were stained with antibodies for Kim-1, a marker for tubular injury (Ichimura et al., 1998; Vaidya et al., 2010; Yang et al., 2010), ssDNA, a marker for apoptotic cells (Elliott et al., 2009), and Ki-67, a proliferation marker (Gerdes et al., 1984). Co-treatment with everolimus and ischemia-reperfusion markedly increased levels of Kim-1 (Fig. 7F-H) and apoptotic cells, as indicated by the number of nuclei with ssDNA immunostaining (Fig. 7I-K). In addition, the results showed that numbers of Ki-67positive nuclei were significantly decreased in the everolimustreated rats (Fig. 7L-N).

\subsection{Effects of cisplatin on the mTOR pathway in the kidney}

To clarify the effects of cisplatin on the mTOR pathway in the kidney, we examined LC3-II and pS6 levels 1, 2, 4, and 7 days after administration. Cisplatin was used as a typical model of druginduced nephrotoxicity; it was taken into renal proximal tubular cells via membrane transporters (Yonezawa and Inui, 2011) such that it exerted its cytotoxicity specifically in proximal tubular cells. The levels of LC3-II were significantly lower in kidneys treated with cisplatin than in normal rat kidneys (Fig. 8A and B). In addition, we observed increased phosphorylation of Ulk1 1 and 2 days after administration (Fig. 8A and C). The day after administration, the levels of p-S6, but not total S6 levels, significantly increased (Fig. 8A, D, and E). These results clearly showed that the mTOR pathway was activated 1 day after exposure to cisplatin. $\mathrm{PCr}$
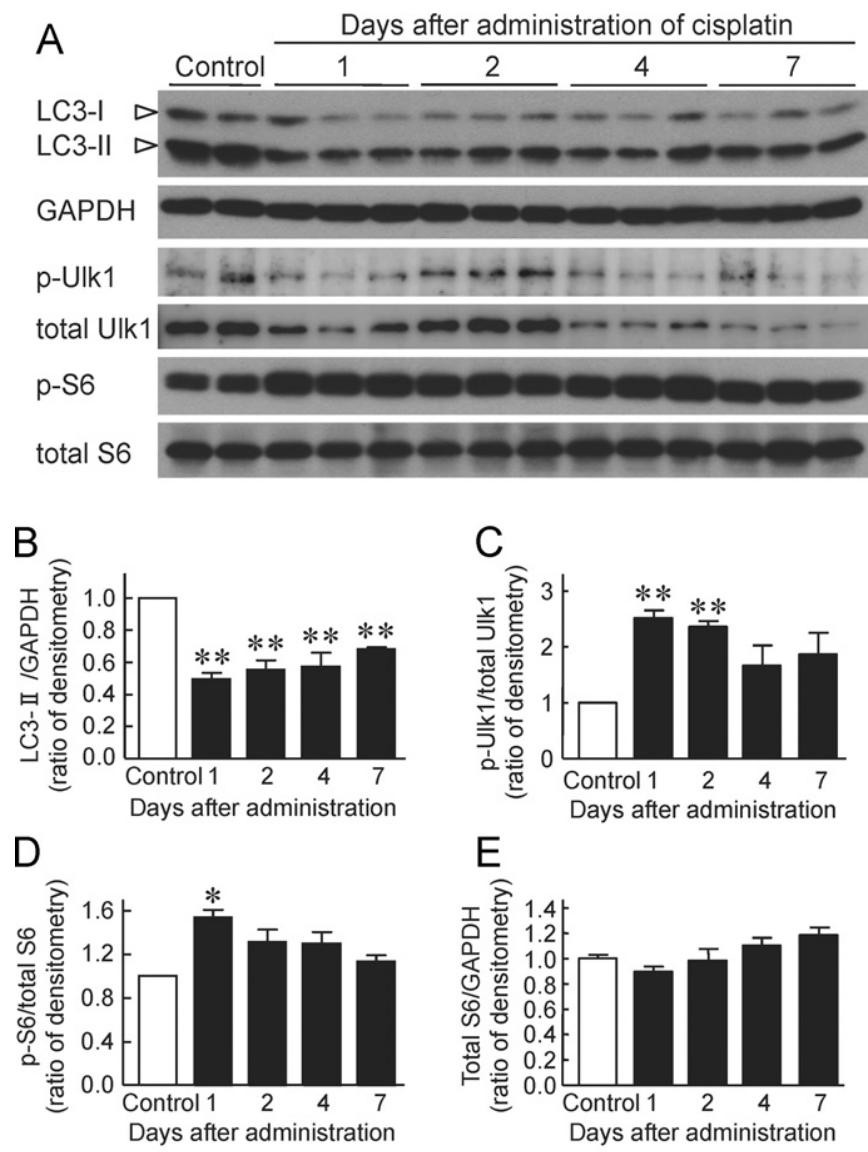

$\mathrm{F}$

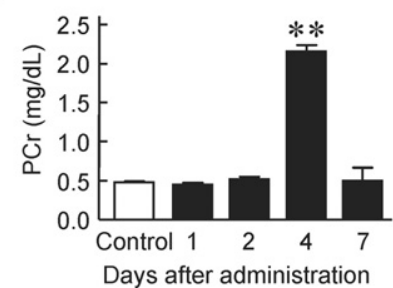

$G$

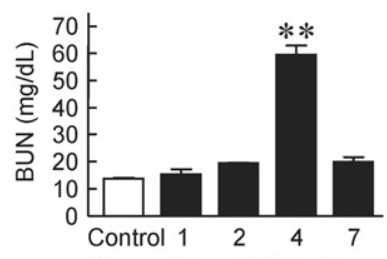

Days after administration

Fig. 8. Effects of cisplatin on autophagy in rat kidneys. Rats were intraperitoneally administered cisplatin ( $5 \mathrm{mg} / \mathrm{kg}$ body weight). Kidneys were collected $1,2,4$, and 7 days after administration. As a control group, rats were administered vehicle, and kidneys were collected 2 days after administration. The number of rats in each group was 6. (A)-(E) Whole-kidney homogenates were subjected to Western blotting. The expression levels of LC3, total Ulk1, p-Ulk1, total S6, p-S6, and GAPDH were examined. (B)-(E) The relative densities of the bands in each lane were determined. (F), (G) Renal function was assessed by measuring PCr and blood urea nitrogen levels. Multiple comparisons were performed using Dunnett's 2-tailed test. ${ }^{*} P<0.05,{ }^{* *} P<0.01$, significantly different from control rat kidneys. 
LC3-I

LC3-II

Control E-

\section{GAPDH}
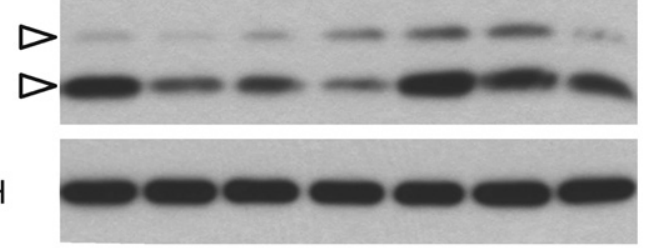

\section{p-Ulk1}

total Ulk1

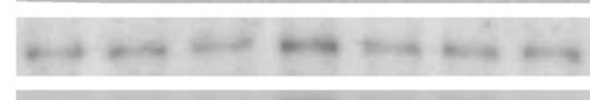

p-S6

total S6

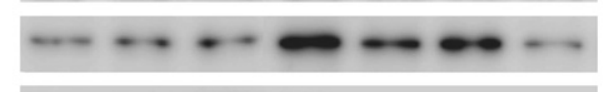

B
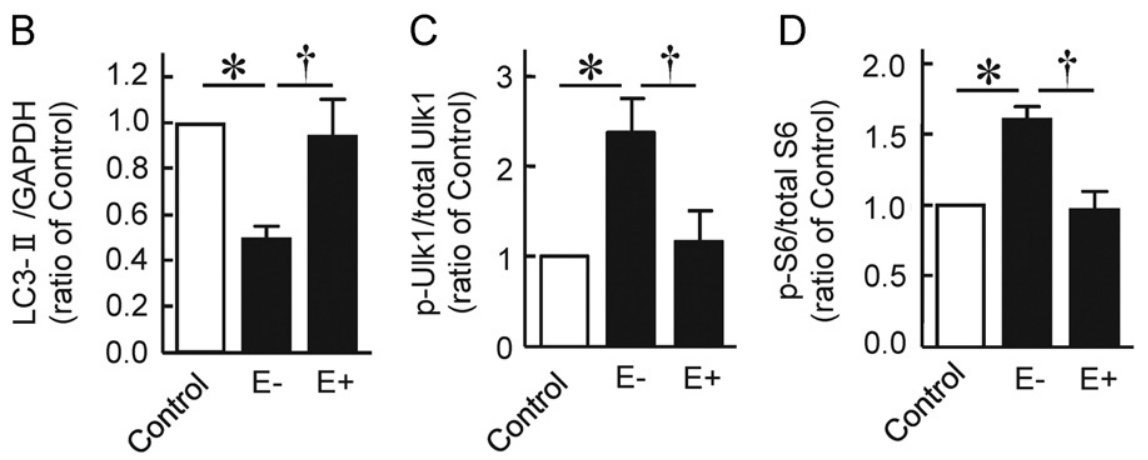

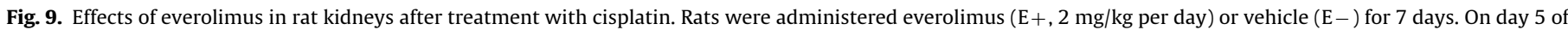

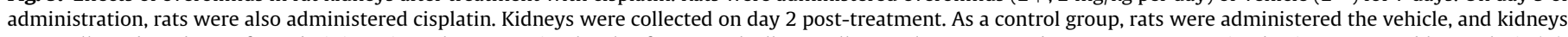

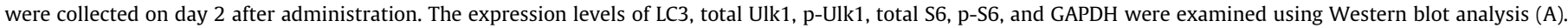
The relative densities of the bands in each lane were determined (B)-(D). ${ }^{*} P<0.05,{ }^{\dagger} P<0.05$ show significant difference.

and blood urea nitrogen levels significantly increased 4 days after administration (Fig. 8F and G).

\subsection{Effects of everolimus in cisplatin-induced nephropathy}

Next, we examined the effects of everolimus on the levels of LC3-II, p-Ulk1, and p-S6 in the kidney after treatment with cisplatin. Exposure to cisplatin markedly decreased the levels of LC3-II and increased the levels of p-Ulk1 and p-S6 in the kidneys; however, everolimus treatment resulted in the accumulation of LC3-II (Fig. 9A and B and Fig. 10C-E) and dephosphorylation of Ulk1 and S6 (Fig. 9A, C and D), which indicated that the mTOR pathway regulated the levels of LC3-II in the kidney after cisplatin treatment.

After co-treatment with everolimus and cisplatin, the $\mathrm{PCr}$ levels were significantly higher than those in control rats (Fig. 10A), suggesting that mTOR inhibition with everolimus worsened renal function. Furthermore, kidney weight tended to be altered by everolimus treatment (Fig. 10B). We also explored the effects of everolimus on the levels of Kim-1 and apoptosis. Although not statistically significant, the number of proximal tubules with Kim-1 immunostaining nearly doubled after cotreatment with everolimus and cisplatin (Fig. 10F-H). Conversely, the number of apoptotic cells was comparable in the treatment and control groups (Fig. 10I-K). However, everolimus treatment significantly decreased the number of Ki-67-positive nuclei in tubular epithelial cells (Fig. 10L-N).

\subsection{Quantification of urinary $L C 3$}

We next examined whether LC3 protein was present in rat urine. After co-treatment with everolimus and cisplatin, LC3-I and LC3-II were detected in the urine (Fig. 11A). In addition, we confirmed that two antibodies produced using different epitopes of LC3 could detect both LC3-I and LC3-II in the urine. To quantify the concentration of LC3 in rat urine after everolimus treatment, an LC3 sandwich ELISA was constructed using these two antibodies. A standard curve was generated with serial dilutions of a synthetic peptide of LC3 starting with $500 \mathrm{ng} / \mathrm{mL}$ (Fig. 11B). The lower limit of detection - defined as the lowest LC3 peptide concentration that was significantly differentiated from 0 (assay blank) by an unpaired t test $(n=3, P<0.001)$ - was $0.122 \mathrm{ng} / \mathrm{mL}$. The coefficient of variation obtained for each standard from 0.122 to $500 \mathrm{ng} / \mathrm{mL}$ was $<10 \%$.

Next, urinary LC3 concentration was measured in rats taken from the ischemia-reperfusion and cisplatin groups described above. The mean urinary LC3 concentration in the everolimustreated group was significantly higher than that in the vehicletreated group (Fig. 11C and D).

\section{Discussion}

Recent findings have demonstrated that mTOR inhibitors have therapeutic effects in progressive kidney diseases, including polycystic kidney disease and diabetic nephropathy (Huber et al., 2011), 
A

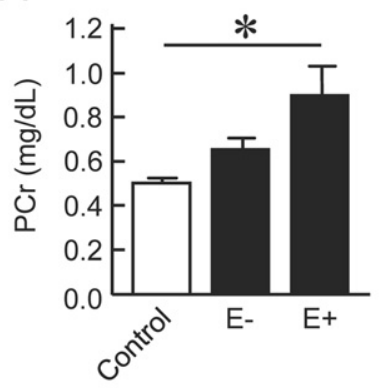

B

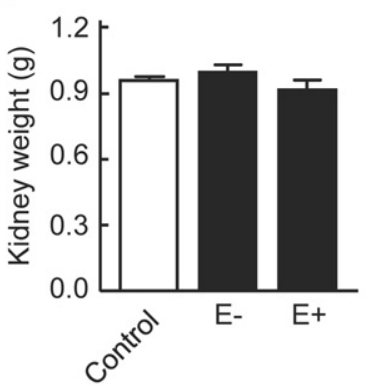

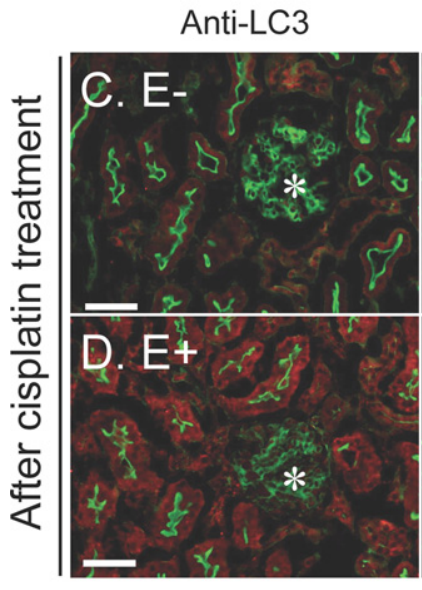
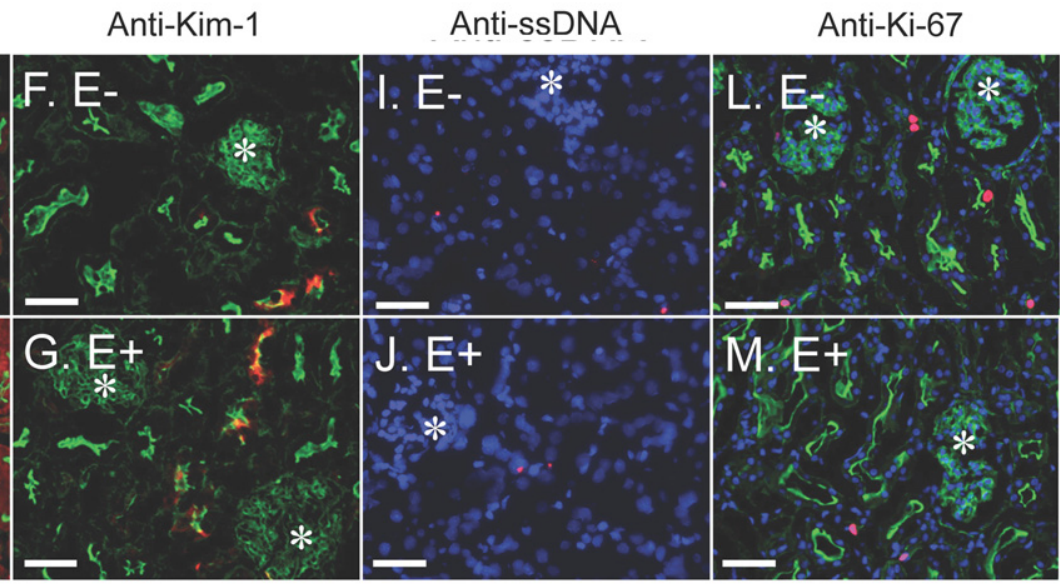

$E$

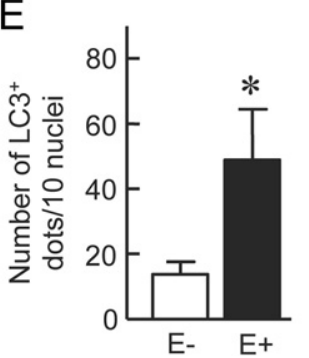

$\mathrm{H}$

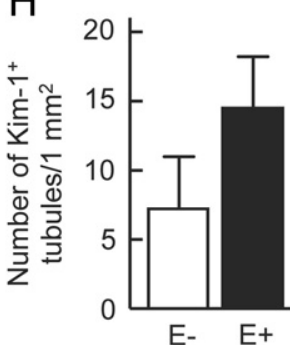

$\mathrm{K}$

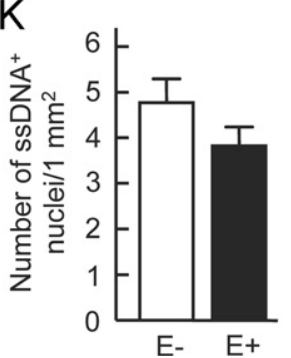

$\mathrm{N}$

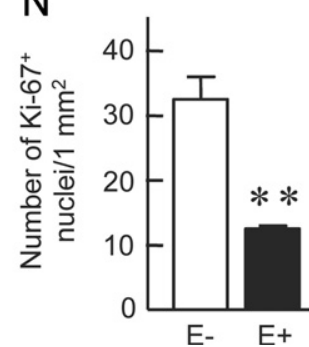

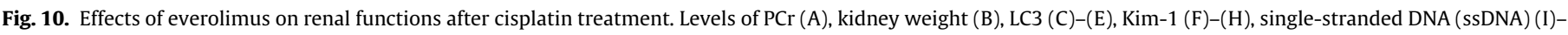

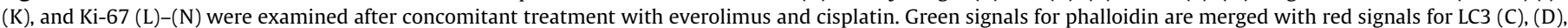

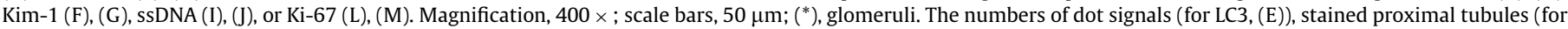

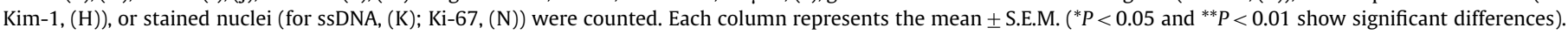

but mTOR inhibitors can also cause renal toxicity (Lieberthal et al., 2001; Nishihara et al., 2010). Therefore, the details of the action of mTOR inhibitors in the kidney need to be clarified to aid the development of targeted therapy against kidney disease.

Ulk1 has been shown to be necessary for the induction of autophagy by mTOR inhibitors (Chan et al., 2007); however, the roles of Ulk1 in the antiproliferative effects of everolimus remain unclear. Immunofluorescence analysis showed expression of Ulk1 and LC3 proteins in the proximal tubular epithelial cells of rat kidneys (Fig. 2). The results suggested that the mTOR-Ulk1 pathway had active roles in the proximal tubular epithelial cells. They also indicated that the monitoring of LC3-II levels in the kidney was useful for evaluating mTOR activity and the efficacy of mTOR inhibition with everolimus in proximal tubular cells. We found that the accumulation of LC3-II resulting from everolimus treatment accompanied the prevention of cell proliferation in renal tubular epithelial cell lines (Fig. 3A and B). Notably, treatment with siUlk1 reduced the antiproliferative effects of everolimus in NRK-52E cells (Fig. 3D-G). These results showed that Ulk1 and its downstream cellular events, such as autophagy, had key roles in the antiproliferative effects of everolimus.

After ischemia-reperfusion injury, renal tubular epithelial cells rapidly enter the cell cycle to adapt to the loss of neighboring cells by proliferating and replacing the dead cells (Venkatachalam et al., 1978). Previous studies in mouse and rat kidneys have suggested that the mTOR pathway is involved in the repair of renal tubular cells after acute injury (Gonçalves et al., 2006; Lieberthal et al., 2001). To characterize roles of the mTOR pathway after ischemiareperfusion injury, we examined influences of mTOR activation on autophagy in ischemia-reperfusion injury. We found that the levels of LC3-II in the kidneys decreased when the mTOR pathway was activated (Fig. 5). In contrast, co-treatment with everolimus and ischemia-reperfusion resulted in the accumulation of renal LC3-II (Fig. 6). These results suggested that the activated mTOR pathway after ischemia-reperfusion was involved in decreasing LC3-II levels in the kidney. We also found that Kim-1 levels and the number of apoptotic cells in the renal cortex increased after everolimus treatment (Fig. 7). The results from tubular cell lines (Fig. 3) 
A

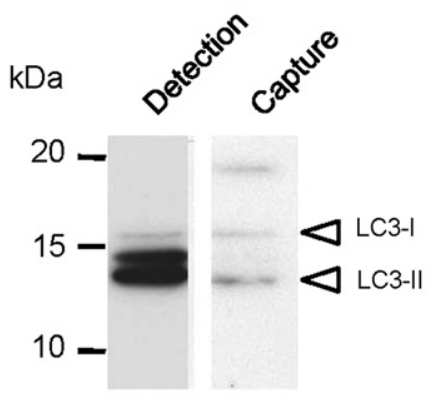

C

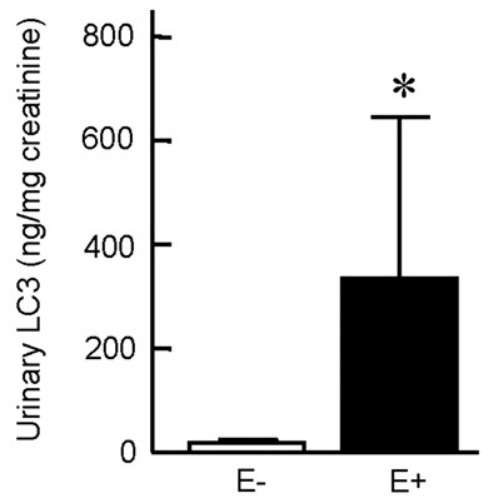

B

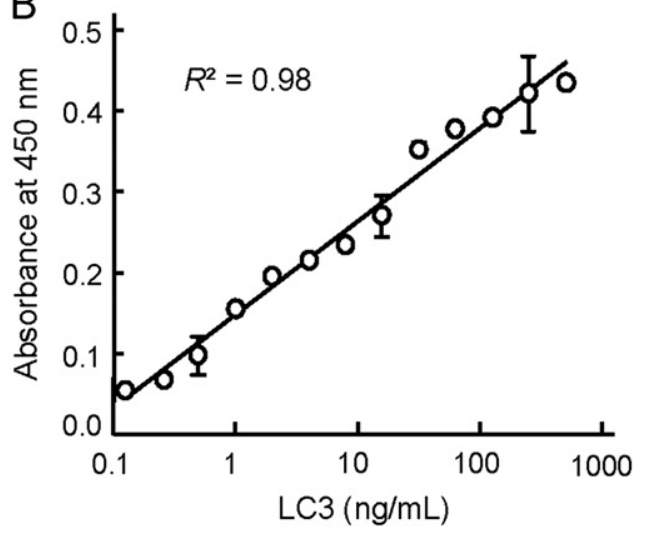

D

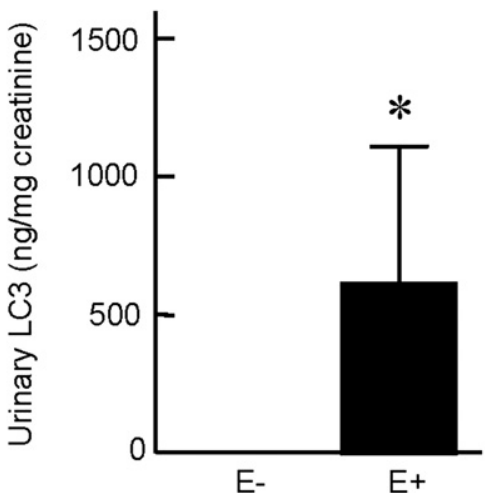

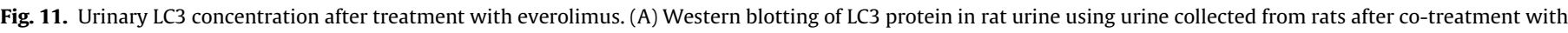

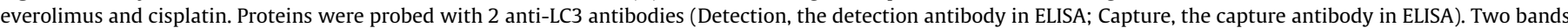

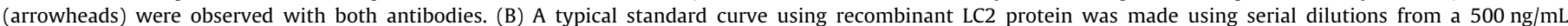

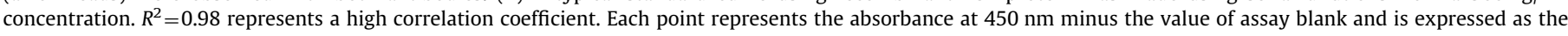

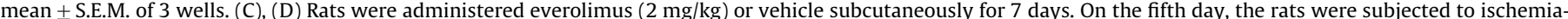

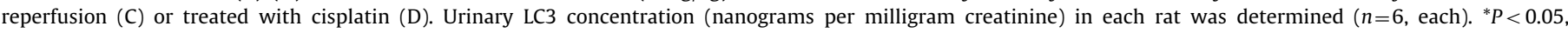
significantly different from vehicle treated rats.

suggested that mTOR inhibition prevented cell proliferation in the proximal tubules after ischemia-reperfusion by inducing LC3-II accumulation. These results suggest that the proximal tubular cells underwent autophagy-mediated cell death after treatment with everolimus and ischemia-reperfusion. Shimizu et al. demonstrated autophagy-dependent programmed cell death in embryonic fibroblasts from Bax/Bak double-knockout mice (Shimizu et al., 2004). Furthermore, it was reported that cytotoxicity of temozolomide and sirolimus against human malignant glioma cells was caused by induction of autophagy (Iwamaru et al., 2007; Kanzawa et al., 2004). These findings suggest that the use of mTOR inhibitors in acute kidney injury could mediate cellular demise of proximal tubules via the direct self-destructive potential of excessive autophagy.

After exposure to cisplatin, the activation of cell survival pathways, including those of phosphoinositide-3 kinase and Akt/protein kinase B, in proximal tubules was observed (Kuwana et al., 2008). Inhibition of these pathways caused severe tubular injury, indicating compensative roles of these pathways in the maintenance of renal function. In this study, we found mTOR pathway activation after cisplatin administration (Fig. 8) and noted that everolimus pretreatment diminished renal function and prevented cell proliferation in proximal tubules (Fig. 10). These results indicated that the active mTOR pathway in proximal tubular epithelial cells after cisplatin administration served as a cell survival pathway. Therefore, cotreatment of everolimus and cisplatin in cancer therapy could cause severe renal dysfunction by preventing the cell survival functions of proximal tubular cells.
Recent studies have shown that MTOR and AMP-activated protein kinase (AMPK) are the most important regulators of Ulk1-mediated autophagy (Egan et al., 2011; Kim et al., 2011). mTOR inhibits the phosphorylation-mediated activation of Ulk1 at Ser 757 and disrupts the interaction between Ulk1 and AMPK. We found significant increase in Ulk1 phosphorylation (Ser 757) in the rat kidneys after ischemia-reperfusion injury and treatment with cisplatin (Figs. 5, 6, 8, and 9): however, we found a decrease in the total protein expression levels of Ulk1 in the kidneys after acute injury. Although further studies are required to have a comprehensive understanding of Ulk1 regulation in the kidney, and our results showed direct interaction between mTOR and Ulk1 in the kidney.

Interestingly, ischemia-reperfusion treatment induced significant increase in the total levels of S6 in the kidneys (Fig. 5), but cisplatin treatment did not (Fig. 8). Ribosomal protein S6 plays important roles in cell growth and proliferation (Ruvinsky and Meyuhas, 2006). Previous studies showed that the expression level of S6 protein increased in serum-stimulated cells (Tushinski and Warner, 1982). In this study, a higher number of tubular epithelial cells underwent the cell cycle progression after ischemia-reperfusion (Fig. 7) than after cisplatin treatment (Fig. 10). Therefore, not only the phosphorylation status but also the expression levels of total S6 protein may be the key factors in the progression of tubular cell proliferation.

The profiles of renal LC3-II levels suggested that autophagic activity in the kidneys was suppressed during the recovery phase of ischemia-reperfusion injury and cisplatin-induced nephropathy 
at least 1 day after treatment (Figs. 5, 8). Furthermore, mTOR inhibition with everolimus restored the autophagic activity in rat kidneys subjected to ischemia-reperfusion or cisplatin administration (Figs. 6, 9). Accordingly, autophagy in tubular epithelial cells could be suppressed through the activation of the mTOR pathway during the recovery phase of acute kidney injury. Conversely, a recent study in mice without the Atg5 gene in proximal tubular cells showed that constitutive suppression of autophagy resulted in severe tubular dysfunction after ischemia-reperfusion (Kimura et al., 2011). The results indicated that autophagy has protective roles against ischemia-reperfusion injury. In rat liver, activation of autophagy has been observed within 15 min after ischemia-reperfusion treatment (Gotoh et al., 2009). Taken together, these results suggest that autophagy in renal tubular epithelial cells occurs in response to ischemia-reperfusioninduced hypoxia immediately after ischemia-reperfusion treatment, but autophagy is suppressed through the activation of the mTOR pathway during the regeneration phase of tubular injury.

Urinary proteins have been found to be sensitive biomarkers of drug-induced nephropathy, with dose-dependent increases in urinary concentration correlated to the degree of tissue damage (Ferguson et al., 2008). Our results indicated that the effects of everolimus on protein synthesis, autophagy, and cell proliferation in the kidneys, especially in proximal tubular cells, were detected by the accumulation of LC3-II (Figs. 5, 6, 8, and 9). These findings encouraged us to assess the availability of urinary LC3 as a non-invasive marker. Using the ELISA for LC3, we detected LC3 protein in rat urine. We also found that everolimus pretreatment markedly increased the urinary LC3 levels in rats with ischemia-reperfusion injury and cisplatin-induced nephropathy (Fig. 11C and D). Although further investigation of the underlying mechanisms of this effect is required, these results suggest that urinary LC3 could be a biological marker for mTOR inhibition during acute kidney injury.

The present results, which reveal the molecular events underlying everolimus activity in the kidney, advance knowledge about the roles of the mTOR pathway in the pathophysiology of acute kidney injury. The hypothesized molecular mechanisms of mTOR-mediated autophagy in proximal tubular epithelial cells are summarized in Fig. 12. After exposure to ischemia-reperfusion or nephrotoxicants, the mTOR pathway in the proximal tubular epithelial cells became active to promote tubular cell regeneration and suppress autophagy (Fig. 12A). Activation of the mTOR pathway in the proximal tubules inhibited the phosphorylation of Ulk1, which possibly disrupted the interaction between activated p-Ulk1 and AMPK. The use of everolimus resulted in the accumulation of LC3-II in the cells, however (Fig. 12B). Similar to the findings shown by Kim et al. that rapamycin treatment in HEK293 cells inhibited the phosphorylation of Ulk1 but did not activate AMPK (Kim et al., 2011), our findings showed that everolimus treatment activated Ulk1 by its phosphorylation in the proximal tubules in an AMPK-independent manner. However, the precise role of AMPK in Ulk1 activation should be addressed in future studies. Although the origin of the excretion of LC3-II or LC3-I from epithelial cells into urine was unclear (i.e., from living cells or from dead cells), our results showed that the presence of LC3 in urine could indicate renal tubular injury through mTOR inhibition with everolimus in response to acute proximal tubular damage such as cisplatin treatment. These results suggest the usefulness of additional studies to determine the clinical significance of LC3 as a urinary biomarker in pharmacotherapy with mTOR inhibitors.

In conclusion, we have discovered a novel role for the mTOR pathway in proximal tubular cells: the regulation of autophagy. Our data suggested that the use of mTOR inhibitors in acute kidney injury activates Ulk1 and autophagy, eventually impairing tubular regeneration after acute injury. These findings provide important information for the development of appropriate protocols for the clinical application of MTOR inhibitors.
A

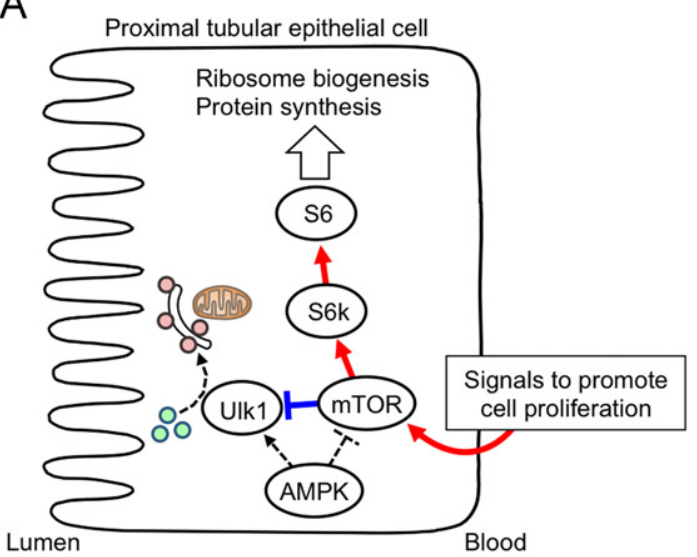

$\mathrm{B}$

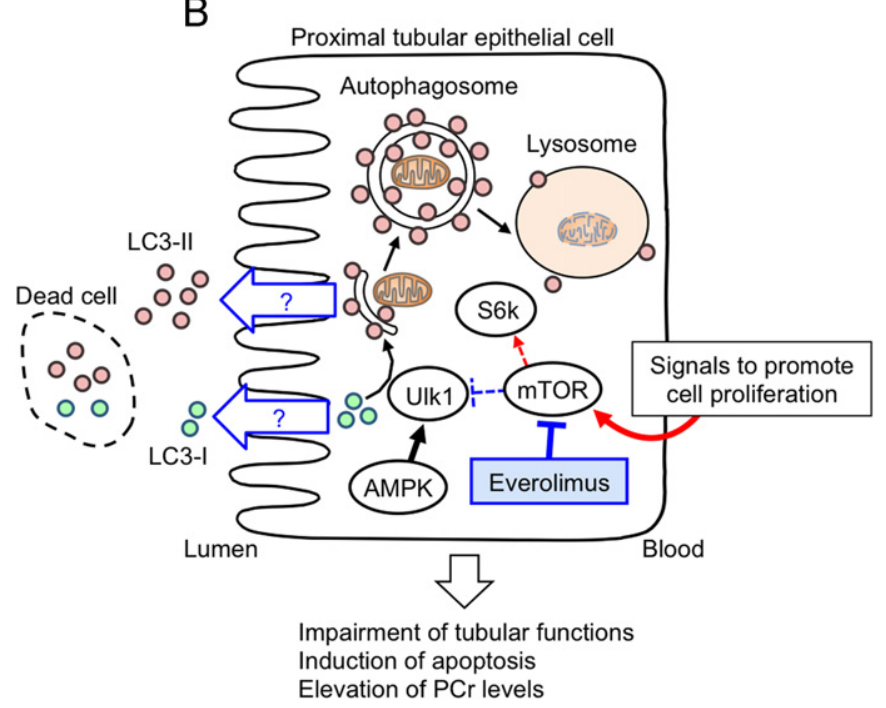

Fig. 12. The hypothesized mechanisms of mammalian target of rapamycin (mTOR) inhibitor action in proximal tubular epithelial cells. (A) During the recovery phase of nephrotoxicants-induced tubular injury, the mTOR pathway in proximal tubular cells is activated to promote cell proliferation. (B) Everolimus treatment exerts antiproliferative effects by blocking cell survival pathways. The quantification of urinary LC3 protein could be beneficial in predicting outcomes of treatment with mTOR inhibitors.

\section{Acknowledgement}

This work was supported in part by a grant-in-aid for Research on Biological Markers for New Drug Development and Health and Labour Sciences Research Grants from the Ministry of Health, Labour and Welfare of Japan (08062855 to S. Masuda); by a Funding Program for Next Generation World-Leading Researchers (NEXT Program: LS073 to S. Masuda) initiated by the Council for Science and Technology Policy of the Japan Society for the Promotion of Science; and by a Grant-in-Aid for Scientific Research (A) (20249036 to K. Inui), a Grant-in-Aid for Young Scientists (A) (21689017 to S. Masuda), and a Grant-in-Aid for JSPS Fellows (20-2438 to K. Nishihara) from the Ministry of Education, Science, Culture, Sports and Technology of Japan.

\section{References}

Bonventre, J.V., Weinberg, J.M., 2003. Recent advances in the pathophysiology of ischemic acute renal failure. J. Am. Soc. Nephrol. 14, 2199-2210.

Chan, E.Y., Kir, S., Tooze, S.A., 2007. siRNA screening of the kinome identifies ULK1 as a multidomain modulator of autophagy. J. Biol. Chem. 282, 25464-25474. 
Egan, D.F., Shackelford, D.B., Mihaylova, M.M., Gelino, S., Kohnz, R.A., Mair, W., Vasquez, D.S., Joshi, A., Gwinn, D.M., Taylor, R., Asara, J.M., Fitzpatrick, J., Dillin, A., Viollet, B., Kundu, M., Hansen, M., Shaw, R.J., 2011. Phosphorylation of ULK1 (hATG1) by AMP-activated protein kinase connects energy sensing to mitophagy. Science 331, 456-461.

Ekberg, H., Tedesco-Silva, H., Demirbas, A., Vítko, S., Nashan, B., Gürkan, A., Margreiter, R., Hugo, C., Grinyó, J.M., Frei, U., Vanrenterghem, Y., Daloze, P., Halloran, P.F., Study, E.-S., 2007. Reduced exposure to calcineurin inhibitors in renal transplantation. N. Engl. J. Med. 357, 2562-2575.

Elliott, M.R., Chekeni, F.B., Trampont, P.C., Lazarowski, E.R., Kadl, A., Walk, S.F., Park, D., Woodson, R.I., Ostankovich, M., Sharma, P., Lysiak, J.J., Harden, T.K., Leitinger, N., Ravichandran, K.S., 2009. Nucleotides released by apoptotic cells act as a find-me signal to promote phagocytic clearance. Nature 461, 282-286.

Esposito, C., Grosjean, F., Torreggiani, M., Esposito, V., Mangione, F., Villa, L., Sileno, G., Rosso, R., Serpieri, N., Molinaro, M., Fasoli, G., Dal Canton, A., 2011. Sirolimus prevents short-term renal changes induced by ischemiareperfusion injury in rats. Am. J. Nephrol. 33, 239-249.

Ferguson, M.A., Vaidya, V.S., Bonventre, J.V., 2008. Biomarkers of nephrotoxic acute kidney injury. Toxicology 245, 182-193.

Gerdes, J., Lemke, H., Baisch, H., Wacker, H.H., Schwab, U., Stein, H., 1984. Cell cycle analysis of a cell proliferation-associated human nuclear antigen defined by the monoclonal antibody Ki-67. J. Immunol. 133, 1710-1715.

Gonçalves, G.M., Cenedeze, M.A., Feitoza, C.Q., Wang, P.M., Bertocchi, A.P., Damião, M.J., Pinheiro, H.S., Antunes Teixeira, V.P., dos Reis, M.A., Pacheco-Silva, A. Câmara, N.O., 2006. The role of heme oxygenase 1 in rapamycin-induced renal dysfunction after ischemia and reperfusion injury. Kidney Int. 70, 1742-1749.

Gotoh, K., Lu, Z., Morita, M., Shibata, M., Koike, M., Waguri, S., Dono, K., Doki, Y. Kominami, E., Sugioka, A., Monden, M., Uchiyama, Y., 2009. Participation of autophagy in the initiation of graft dysfunction after rat liver transplantation. Autophagy 5, 351-360.

Huber, T.B., Walz, G., Kuehn, E.W., 2011. mTOR and rapamycin in the kidney: signaling and therapeutic implications beyond immunosuppression. Kidney Int. 79, 502-511.

Ichimura, T., Bonventre, J.V., Bailly, V., Wei, H., Hession, C.A., Cate, R.L., Sanicola, M. 1998. Kidney injury molecule-1 (KIM-1), a putative epithelial cell adhesion molecule containing a novel immunoglobulin domain, is up-regulated in renal cells after injury. J. Biol. Chem. 273, 4135-4142.

Iwamaru, A., Kondo, Y., Iwado, E., Aoki, H., Fujiwara, K., Yokoyama, T., Mills, G.B., Kondo, S., 2007. Silencing mammalian target of rapamycin signaling by small interfering RNA enhances rapamycin-induced autophagy in malignant glioma cells. Oncogene 26, 1840-1851.

Kahn, D., Spearman, C.W., Mall, A., Shepherd, E., Engelbrecht, G., Lotz, Z., Tyler, M., 2005. The effect of rapamycin on the healing of the ureteric anastomosis and wound healing. Transplant Proc. 37, 830-831.

Kanzawa, T., Germano, I.M., Komata, T., Ito, H., Kondo, Y., Kondo, S., 2004. Role of autophagy in temozolomide-induced cytotoxicity for malignant glioma cells. Cell Death Differ. 11, 448-457.

Kim, J., Kundu, M., Viollet, B., Guan, K.L., 2011. AMPK and mTOR regulate autophagy through direct phosphorylation of Ulk1. Nat. Cell. Biol. 13, 132-141.

Kimura, T., Takabatake, Y., Takahashi, A., Kaimori, J.Y., Matsui, I., Namba, T. Kitamura, H., Niimura, F., Matsusaka, T., Soga, T., Rakugi, H., Isaka, Y., 2011. Autophagy protects the proximal tubule from degeneration and acute ischemic injury. J. Am. Soc. Nephrol. 22, 902-913.

Klionsky, D.J., Abeliovich, H., Agostinis, P., Agrawal, D.K., Aliev, G., Askew, D.S., Baba, M., Baehrecke, E.H., Bahr, B.A., Ballabio, A., Bamber, B.A., Bassham, D.C., Bergamini, E., Bi, X., Biard-Piechaczyk, M., Blum, J.S., Bredesen, D.E., Brodsky, J.L., Brumell, J.H., Brunk, U.T., Bursch, W., Camougrand, N., Cebollero, E., Cecconi, F., Chen, Y., Chin, L.S., Choi, A., Chu, C.T., Chung, J., Clarke, P.G., Clark, R.S., Clarke, S.G., Clavé, C., Cleveland, J.L., Codogno, P., Colombo, M.I., CotoMontes, A., Cregg, J.M., Cuervo, A.M., Debnath, J., Demarchi, F., Dennis, P.B., Dennis, P.A., Deretic, V., Devenish, R.J., Di Sano, F., Dice, J.F., Difiglia, M., DineshKumar, S., Distelhorst, C.W., Djavaheri-Mergny, M., Dorsey, F.C., Dröge, W., Dron, M., Dunn, W.A., Duszenko, M., Eissa, N.T., Elazar, Z., Esclatine, A., Eskelinen, E.L., Fésüs, L., Finley, K.D., Fuentes, J.M., Fueyo, J., Fujisaki, K., Galliot, B., Gao, F.B., Gewirtz, D.A., Gibson, S.B., Gohla, A., Goldberg, A.L., Gonzalez, R. González-Estévez, C., Gorski, S., Gottlieb, R.A., Häussinger, D., He, Y.W., Heidenreich, K., Hill, J.A., Høyer-Hansen, M., Hu, X., Huang, W.P., Iwasaki, A., Jäättelä, M., Jackson, W.T., Jiang, X., Jin, S., Johansen, T., Jung, J.U., Kadowaki, M., Kang, C., Kelekar, A., Kessel, D.H., Kiel, J.A., Kim, H.P., Kimchi, A., Kinsella, T.J., Kiselyov, K., Kitamoto, K., Knecht, E., Komatsu, M., Kominami, E., Kondo, S., Kovács, A.L., Kroemer, G., Kuan, C.Y., Kumar, R., Kundu, M., Landry, J., Laporte, M., Le, W., Lei, H.Y., Lenardo, M.J., Levine, B., Lieberman, A., Lim, K.L., Lin, F.C., Liou, W., Liu, L.F., Lopez-Berestein, G., López-Otín, C., Lu, B., Macleod, K.F., Malorni, W., Martinet, W., Matsuoka, K., Mautner, J., Meijer, A.J., Meléndez, A.,
Michels, I., Miotto, G., Mistiaen, W.P., Mizushima, N., Mograbi, B., Monastyrska, I, Moore, M.N., Moreira, P. Moriyasu, Y. Motyl, T., Münz, C., Murphy, L.O. Naqvi, N.I., Neufeld, T.P., Nishino, I., Nixon, R.A., Noda, T., Nürnberg, B., Ogawa, M., Oleinick, N.L., Olsen, L.J., Ozpolat, B., Paglin, S., Palmer, G.E., Papassideri, I., Parkes, M., Perlmutter, D.H., Perry, G., Piacentini, M., Pinkas-Kramarski, R., Prescott, M., Proikas-Cezanne, T., Raben, N., Rami, A., Reggiori, F., Rohrer, B., Rubinsztein, D.C., Ryan, K.M., Sadoshima, J., Sakagami, H., Sakai, Y., Sandri, M., Sasakawa, C., Sass, M., Schneider, C., Seglen, P.O., Seleverstov, O., Settleman, J., Shacka, J.J., Shapiro, I.M., Sibirny, A., Silva-Zacarin, E.C., Simon, H.U., Simone, C., Simonsen, A., Smith, M.A., Spanel-Borowski, K., Srinivas, V., Steeves, M. Stenmark, H., Stromhaug, P.E., Subauste, C.S., Sugimoto, S., Sulzer, D., Suzuki, T. Swanson, M.S., Tabas, I., Takeshita, F., Talbot, N.J., Tallóczy, Z., Tanaka, K. Tanida, I., Taylor, G.S., Taylor, J.P., Terman, A., Tettamanti, G., Thompson, C.B., Thumm, M., Tolkovsky, A.M., Tooze, S.A., Truant, R., Tumanovska, L.V. Uchiyama, Y., Ueno, T., Uzcátegui, N.L., van der Klei, I., Vaquero, E.C., Vellai, T., Vogel, M.W., Wang, H.G., Webster, P., Wiley, J.W., Xi, Z., Xiao, G., Yahalom, J., Yang, J.M., Yap, G., Yin, X.M., Yoshimori, T., Yu, L., Yue, Z., Yuzaki, M., Zabirnyk, O., Zheng, X., Zhu, X., Deter, R.L., 2008. Guidelines for the use and interpretation of assays for monitoring autophagy in higher eukaryotes. Autophagy 4 $151-175$

Kuwana, H., Terada, Y., Kobayashi, T., Okado, T., Penninger, J.M., Irie-Sasaki, J., Sasaki, T., Sasaki, S., 2008. The phosphoinositide-3 kinase gamma-Akt pathway mediates renal tubular injury in cisplatin nephrotoxicity. Kidney Int. 73, 430-445.

Lehmkuhl, $\mathrm{H}$, Ross, $\mathrm{H}$, Eisen, $\mathrm{H}$, Valantine, $\mathrm{H}, 2005$. Everolimus (certican) in heart transplantation: optimizing renal function through minimizing cyclosporine exposure. Transplant Proc. 37, 4145-4149.

Levine, B., Kroemer, G., 2008. Autophagy in the pathogenesis of disease. Cell 132 27-42.

Lieberthal, W., Fuhro, R., Andry, C.C., Rennke, H., Abernathy, V.E., Koh, J.S., Valeri R., Levine, J.S., 2001. Rapamycin impairs recovery from acute renal failure: role of cell-cycle arrest and apoptosis of tubular cells. Am. J. Physiol. Renal. Physiol. 281, F693-706.

Mizushima, N., Yamamoto, A., Matsui, M., Yoshimori, T., Ohsumi, Y., 2004. In vivo analysis of autophagy in response to nutrient starvation using transgenic mice expressing a fluorescent autophagosome marker. Mol. Biol. Cell 15, 1101-1111.

Mizushima, N., Yoshimori, T., Levine, B., 2010. Methods in mammalian autophagy research. Cell 140, 313-326.

Nakagawa, S., Masuda, S., Nishihara, K., Inui, K., 2010. mTOR inhibitor everolimus ameliorates progressive tubular dysfunction in chronic renal failure rats. Biochem. Pharmacol. 79, 67-76.

Nishihara, K., Masuda, S., Nakagawa, S., Yonezawa, A., Ichimura, T., Bonventre, J.V., Inui, K., 2010. Impact of cyclin B2 and cell division cycle 2 on tubula hyperplasia in progressive chronic renal failure rats. Am. J. Physiol. Renal. Physiol. 298, F923-934.

Ruvinsky, I., Meyuhas, O., 2006. Ribosomal protein S6 phosphorylation: from protein synthesis to cell size. Trends. Biochem. Sci. 31, 342-348.

Schweiger, M., Wasler, A., Prenner, G., Stiegler, P., Stadlbauer, V., Schwarz, M. Tscheliessnigg, K., 2006. Everolimus and reduced cyclosporine trough levels in maintenance heart transplant recipients. Transpl. Immunol. 16, 46-51.

Shimizu, S., Kanaseki, T., Mizushima, N., Mizuta, T., Arakawa-Kobayashi, S. Thompson, C.B., Tsujimoto, Y., 2004. Role of Bcl-2 family proteins in a nonapoptotic programmed cell death dependent on autophagy genes. Nat. Cell Biol. 6, 1221-1228.

Tushinski, R.J., Warner, J.R., 1982. Ribosomal proteins are synthesized preferentially in cells commencing growth. J. Cell Physiol. 112, 128-135.

Vaidya, V.S., Ozer, J.S., Dieterle, F., Collings, F.B., Ramirez, V., Troth, S., Muniappa, N., Thudium, D., Gerhold, D., Holder, D.J., Bobadilla, N.A., Marrer, E., Perentes, E., Cordier, A., Vonderscher, J., Maurer, G., Goering, P.L., Sistare, F.D., Bonventre J.V., 2010. Kidney injury molecule-1 outperforms traditional biomarkers of kidney injury in preclinical biomarker qualification studies. Nat. Biotechnol. $28,478-485$

Venkatachalam, M.A., Bernard, D.B., Donohoe, J.F., Levinsky, N.G., 1978. Ischemic damage and repair in the rat proximal tubule: differences among the S1, S2 and S3 segments. Kidney Int. 14, 31-49.

Wullschleger, S., Loewith, R., Hall, M.N., 2006. TOR signaling in growth and metabolism. Cell 124, 471-484.

Yang, L., Besschetnova, T.Y., Brooks, C.R., Shah, J.V., Bonventre, J.V., 2010. Epithelial cell cycle arrest in G2/M mediates kidney fibrosis after injury. Nat. Med. 16, 535-543 531p following 143.

Yonezawa, A., Inui, K., 2011. Organic cation transporter OCT/SLC22A and $\mathrm{H}(+)$ organic cation antiporter MATE/SLC47A are key molecules for nephrotoxicity of platinum agents. Biochem. Pharmacol. 81, 563-568. 